\title{
Możliwość wprowadzenia w prawie łowieckim regulacji dopuszczającej polowanie z łukiem ${ }^{1}$
}

\begin{abstract}
Possibility of introducing regulations admitting hunting with a bow into the Hunting Law (WAP-1449/18): Due to the principle of sustainable development and placement of the Hunting Law in the system of protection of natural environment, admission of archery as a method of hunting on the territory of the Republic of Poland may raise - according to the author - doubts. Extending the arsenal of hunting weapons by a bow could find a justification only in the situation, when, based on independent scientific research, it would confirm the thesis that the bow can be effective for purposes of the hunting economy and can constitute a weapon at least as humanitarian and safe as a hunting firearm.
\end{abstract}

Keywords: hunting, nature protection, Hunting Law, animals

Słowa kluczowe: łowiectwo, ochrona przyrody, prawo łowieckie, zwierzęta

Doktor nauk prawnych, ekspert ds. legislacji BAS; beata.binkowska-artowicz@sejm.gov.pl.

\section{Przedmiot opinii}

Przedmiot opinii stanowi kwestia możliwości wprowadzenia w prawie łowieckim regulacji dopuszczającej polowanie z łukiem, a dodatkowo ocena propozycji podmiotu zewnętrznego zawierającej projekt rozwiązań prawnych oraz ich uzasadnienie ${ }^{2}$.

Opinię przygotowano według stanu prawnego na dzień 21 czerwca $2018 \mathrm{r}$.

W opinii uwzględniono postanowienia następujących aktów prawnych:

- Konstytucja Rzeczypospolitej Polskiej z 2 kwietnia 1997 r., Dz.U. nr 78, poz. 483, ze zm.; dalej: Konstytucja RP,

1 Opinia prawna $w$ sprawie możliwości wprowadzenia $w$ prawie łowieckim regulacji dopuszczajacej polowanie z łukiem sporządzona 21 czerwca 2018 r. na zlecenie przewodniczącego Komisji Rolnictwa i Rozwoju Wsi; BAS-WAP 1449/18.

2 Pismo Polskiego Stowarzyszenia Myślistwa Łuczniczego z 7 maja 2018 r.; dalej: pismo z 7 maja 2018 r. 
- ustawa z 13 października 1995 r. - Prawo łowieckie, t.j. DzU. 2017, poz. 1295, ze zm.; dalej: u.p.ł.;

- ustawa z 21 sierpnia 1997 r. - o ochronie zwierząt, t.j. Dz.U. 2017, poz. 1840, ze zm.; dalej: u.o.z.,

- ustawa z 27 kwietnia 2001 r. - Prawo ochrony środowiska, t.j. Dz.U. 2018, poz. 799 , ze zm.,

- ustawa z 21 maja 1999 r. o broni i amunicji, t.j. Dz.U. 2017, poz. 1839, ze zm.; dalej: u.b.a.

Należy zastrzec, że Biuro Analiz Sejmowych nie jest uprawnione do wiążącej, formalnej oceny propozycji legislacyjnych przygotowanych przez podmioty zewnętrzne. Oceniana propozycja nie może zostać potraktowana jako projekt aktu prawnego, natomiast może stanowić podstawę do stworzenia hipotetycznej koncepcji legislacyjnej, w nawiązaniu do której zaprezentowana zostanie wykładnia odpowiednich przepisów Konstytucji Rzeczypospolitej Polskiej, Prawa łowieckiego oraz regulacji dotyczących ochrony środowiska oraz broni i amunicji.

\section{Uzasadnienie prawne}

\section{Zarys proponowanej koncepcji legislacyjnej}

Propozycja $^{3}$ dotyczy wprowadzenia strzelania z łuku myśliwskiego jako dodatkową formę polowania, obok dozwolonego obecnie tropienia, strzelania z myśliwskiej broni palnej i łowienia sposobami dozwolonymi zwierzyny żywej (zmiana art. 4 ust. 2 u.p.ł.). Propozycja obejmuje także nałożenie obowiązku posiadania zaświadczenia o posiadaniu uprawnień łuczniczych w przypadku wykonywania polowania $\mathrm{z}$ łukiem myśliwskim (wprowadzenie art. 42 ust. 2 pkt 4 u.p.ł.). Proponowana jest również delegacja dla ministra właściwego do spraw środowiska do wydania rozporządzenia określającego warunki i tryb wykonywania polowania z użyciem łuku myśliwskiego (wprowadzenie art. 42 ust. 12 u.p.ł.) oraz wprowadzenie w rozporządzeniu Ministra Środowiska z 23 marca 2005 r. w sprawie szczegółowych warunków wykonywania polowania i znakowania tusz (Dz.U. $\mathrm{nr}$ 61, poz. 548, ze zm.) definicji łuku myśliwskiego, grotu myśliwskiego i strzały myśliwskiej ( $\$ 2$ pkt 19-21 rozporządzenia). Zaproponowano też możliwość użycia łuku myśliwskiego do wykonywania polowania oraz odstrzału zwierząt stanowiących nadzwyczajne zagrożenie dla życia, zdrowia lub gospodarki człowieka oraz do polowania na zwierzynę grubą ( $\$ 3$ ust. 1 oraz ust. 3 rozporządzenia). Przedstawiono propozycję nowego rozdziału 8 rozporządzenia, określającego maksymalną odległość, w jakiej może znajdować się myśliwy od zwierzyny, do której oddaje strzał z łuku oraz siłę naciągu łuku i wagę strzały myśliwskiej przy polowaniach na poszczególne grupy zwierząt ( $\$ 48$ rozporządzenia).

3 Ibidem, cz. I. Proponowane rozwiąania prawne. 


\section{Prawo łowieckie a regulacje dotyczące ochrony środowiska}

$\mathrm{W}$ art. 1 u.p.ł. ustawodawca przewidział, że łowiectwo jest integralnym elementem ochrony środowiska przyrodniczego, co oznacza, że ustawa - Prawo łowieckie została poddana zasadom ochrony środowiska ${ }^{4}$. Wskazuje się, że niedopuszczalnym spłyceniem tej ustawy byłoby dopatrywanie się w niej tylko treści eksploatatorskich, ponieważ jest to przede wszystkim prawo ochronne ${ }^{5}$. Wykonywanie łowiectwa odbywa się z uwzględnieniem interesów ochrony przyrody $\mathrm{y}^{6}$.

Zgodnie z art. 3 u.p.ł.: celem łowiectwa jest: ochrona, zachowanie różnorodności i gospodarowanie populacjami zwierząt łownych; ochrona i kształtowanie środowiska przyrodniczego na rzecz poprawy warunków bytowania zwierzyny; uzyskiwanie możliwie wysokiej kondycji osobniczej i jakości trofeów oraz właściwej liczebności populacji poszczególnych gatunków zwierzyny przy zachowaniu równowagi środowiska przyrodniczego; spetnianie potrzeb społecznych $w$ zakresie uprawiania myślistwa, kultywowania tradycji oraz krzewienia etyki i kultury łowieckiej. W odniesieniu do powyższych celów polityki łowieckiej w doktrynie trafnie podkreśla się, że powinny być one realizowane w zgodzie z Konstytucją RP ${ }^{7}$.

Na mocy art. 5 Konstytucji RP zapewnienie ochrony środowiska stanowi jeden $\mathrm{z}$ podstawowych celów państwa, a sama ochrona środowiska jest jednym $\mathrm{z}$ dóbr prawnych pozwalających na ograniczenie $\mathrm{w}$ drodze ustawy konstytucyjnych wolności i praw (art. 31 ust. 3 Konstytucji RP) ${ }^{8}$. Jak podkreśla się w literaturze przedmiotu, ostatni zwrot art. 5 Konstytucji RP ogranicza wszelką ingerencję w sprawy „środowiska” wymogiem przestrzegania zasady „zrównoważonego rozwoju". Wszędzie tam, gdzie miałoby dochodzić do ingerencji w „środowisko", należy dbać nie tylko o to, aby ingerencja ta była jak najmniejsza (najmniej szkodliwa), lecz by osiagane korzyści społeczne byly co najmniej proporcjonalne, społecznie adekwatne do strat, jakie się wówczas ponosi ${ }^{10}$. Najważniejszą natomiast częścią składową systemu ochrony środowiska jest ochrona przyrody ${ }^{11}$.

$\mathrm{Z}$ art. 127 ust. 2 pkt 3 ustawy - Prawo ochrony środowiska wynika, że ochrona zwierząt oraz roślin jest realizowana w szczególności poprzez ograniczanie

R. Stec, Łowiectwo w prawie polskim i europejskim, Warszawa 2002, s. 182.

5 W. Radecki, Prawo łowieckie, Wrocław 1996, s. 36 i n., cyt. za: R. Stec, Łowiectwo w prawie polskim, op. cit., s. 120.

$6 \quad$ R. Stec, Łowiectwo w prawie polskim, op. cit., s. 38.

7 R. Stec, Uprawianie łowiectwa i prowadzenie gospodarki łowieckiej. Uwarunkowania administracyjnoprawne, cywilnoprawne i organizacyjne, Warszawa 2012, s. 161.

8 M. Bartoszewicz, Komentarz do art. 74 [w:] Konstytucja Rzeczypospolitej Polskiej. Komentarz, M. Haczkowska, Warszawa 2014, s. 155.

9 P. Sarnecki, Komentarz do art. 5 [w:] Konstytucja Rzeczypospolitej Polskiej. Komentarz, t. I, red. L. Garlicki, M. Zubik, Warszawa 2016.

10 Ibidem.

11 W. Radecki, Ustawa o ochronie przyrody. Komentarz, Warszawa 2006, s. 37-41, cyt. za: M. Bartoszewicz, Komentarz do art. 74, op. cit., s. 156. 
możliwości pozyskiwania dziko występujących zwierząt oraz roślin. Z kolei w art. 1 ust. 1 u.o.z. znajduje się tzw. formuła dereifikacyjna, zgodnie z którą: Zwierze, jako istota żyjaca, zdolna do odczuwania cierpienia, nie jest rzecza ${ }^{12}$. Następnie w art. 5 u.o.z. ustawodawca zawarł bezwzględny nakaz humanitarnego traktowania każdego zwierzęcia, a z art. 33 ust. 1a tej ustawy wynika konieczność humanitarnego uśmiercania zwierząt, to jest zadając przy tym minimum cierpienia fizycznego i psychicznego. Wyjątek od reguły zakazującej zabijanie zwierząt znajduje się natomiast w art. 6 ust. 1 pkt 6 u.o.z., zezwalającym na wykonywanie polowań, odstrzałów i ograniczania populacji zwierząt łownych.

$\mathrm{Z}$ powyższego wynika, że wykonywanie łowiectwa musi być podporządkowane podstawowej zasadzie uwzględnienia interesów ochrony przyrody ${ }^{13}$. Należy także zauważyć, że myślistwo jako synonim polowania jest terminem węższym od łowiectwa i jest dziedziną polegającą na zgodnym z prawem i etyką pozyskiwaniu zwierzą ${ }^{14}$. Łowiectwo polega bowiem na gospodarowaniu zwierzyną i nie jest sportem w rozumieniu art. 2 ust. 1 ustawy z 25 czerwca 2010 r. o sporcie (t.j. Dz.U. 2017, poz. 1463 , ze zm. $)^{15}$.

W obecnym stanie prawnym na mocy art. 4 ust. 2 u.p.ł. polowanie oznacza tropienie, strzelanie z myśliwskiej broni palnej, łowienie sposobami dozwolonymi zwierzyny żywej oraz łowienie zwierzyny przy pomocy ptaków łowczych za zgodą ministra właściwego do spraw środowiska - zmierzające do wejścia w jej posiadanie.

Natomiast zgodnie z ust. 3 powyższego przepisu kłusownictwo oznacza działanie zmierzające do wejścia w posiadanie zwierzyny m.in. w sposób niebędący polowaniem. Konsekwentnie, skoro strzelanie $\mathrm{z}$ łuku nie jest strzelaniem z myśliwskiej broni palnej, to działanie zmierzające do wejścia za jego pomocą w posiadanie zwierzyny jest kwalifikowane jako kłusownictwo. Działanie takie stanowi czyn zabroniony (art. 42aa pkt 12 u.p.t.) pod groźbą kary pozbawienia wolności do lat 5 (art. 53 pkt 5 u.p.ł.). W literaturze przedmiotu wymienia się wprost łuki jako zakazaną broń inną niż myśliwskąa ${ }^{16}$ Tytułem przykładu można także wskazać na stanowisko izby wyższej niemieckiego parlamentu federalnego w odniesieniu do regulacji zawartej w niemieckiej ustawie łowieckiej (Bundesjagdgesetz $\left.{ }^{17}\right)$, która $\mathrm{w} \$ 19$ ust. 1 pkt 1 wprost formułuje zakaz strzelania do zwierzyny z broni miotającej: Skoro strzelanie za pomoca luku i strzaly zostało

12 Na mocy art. 2 u.o.z. ustawa ta reguluje postępowanie ze zwierzętami kręgowymi.

13 R. Stec, Łowiectwo w prawie polskim, op. cit., s. 38.

14 R. Stec, Prawo łowieckie. Historia i teraźniejszość, Warszawa 1998, s. 72.

15 E.J. Krześniak, Kluby i organizacje sportowe w prawie polskim. Na tle rozwiązań zagranicznych, 2016, LEX.

16 W. Radecki, Komentarz do art. 53 ustawy - Prawo łowieckie [w:] System prawa karnego, t. 11, Szczególne dziedziny prawa karnego. Prawo karne wojskowe, skarbowe i pozakodeksowe, red. M. Bojarski, Warszawa 2014, s. 823.

17 BGBl. I S. 2849. 
udoskonalone $w$ taki sposób, $w$ który można oddawać strzały ze znacznej odległości z duża dokładnościa, to polowanie za pomoca łuku powinno być zabronione $z$ uwagi na częsty nieodpowiedni skutek takiego strzału oraz związane z tym cierpienie $z$ wierzą $t^{18}$.

Autorzy propozycji dążą natomiast nie tylko do depenalizacji, ale także do zalegalizowania polowania z łukiem.

W piśmie z 7 maja 2018 r. argumentuje się, że badania przeprowadzone na populacji sarny przez 5 lat w Danii wykazały, że postrzelenia stanowią mniej niż 5\% przypadków ${ }^{19}$. Jednakże nie wskazano, przez jaki ośrodek badania zostały przeprowadzone i z jakiej przyczyny wybrano ten gatunek zwierzyny łownej. Wskazano, że impuls bólowy w przypadku celnego strzału zostaje ograniczony do minimum ${ }^{20}$, natomiast nie przytoczono konkretnych wyników badań przeprowadzonych przez niezależnych ekspertów.

W tym miejscu należy zaznaczyć, że z uwagi na prawny charakter opinii nie sposób szerzej odnieść się do argumentacji dotyczącej humanitaryzmu łucznictwa myśliwskiego lub jego braku. Wskazać natomiast trzeba, że z uwagi na wspomnianą już konstytucyjną zasadę zrównoważonego rozwoju dopuszczenie polowania za pomocą łuku może budzić wątpliwości. Zasada ta, jak wskazuje się w orzecznictwie sądowoadministracyjnym, pełni przede wszystkim role dyrektywy wykładni. A to wtedy, gdy pojawiaja się watpliwości co do zakresu obowiązków, rodzaju obowiązków i sposobu ich realizacji, należy posiłkować się zasada zrównoważonego rozwoju. Pełni ona zatem rolę podobna do zasad wspótżycia społecznego czy społeczno-gospodarczego przeznaczenia w prawie cywilnym. W pierwszej kolejności do uwzględniania zasady zrównoważonego rozwoju obowiązany jest ustawodawca $w$ procesie stanowienia prawa ${ }^{21}$. Konsekwencją niezgodności aktu prawnego z zasadą zrównoważonego rozwoju może być zaskarżenie tego aktu do Trybunału Konstytucyjnego ${ }^{22}$.

\section{Cel proponowanej regulacji}

W literaturze przedmiotu nie ulega wątpliwości, że: prawo nie jest celem samym $w$ sobie, jest narzędziem stosowanym do osiagnięcia zamierzonych celów (...). Przyjmuje się, że działalność prawodawcy jest zawsze działalnościa celową. Takim,

18 Drucksache 7/4285 vom 6. November 1975, Sachgebiet 792, Deutscher Bundestag 7. Wahlperiode, s. 19, http://dipbt.bundestag.de/doc/btd/07/042/0704285.pdf [dostęp: 20 czerwca 2018 r.], tłum. własne.

19 J. Kylmä, Rozwój myślistwa łuczniczego w Europie, załącznik do pisma z 7 maja 2018 r.

20 Pismo z 7 maja 2018 r., cz. II. Uzasadnienie do proponowanych zmian prawa łowieckiego, pkt 6 - Impuls bólowy ograniczony do minimum.

${ }^{21}$ Wyrok Wojewódzkiego Sądu Administracyjnego w Gorzowie Wielkopolskim z 25 marca 2009 r., sygn. akt II SA/Go 825/08, http://orzeczenia.nsa.gov.pl/cbo/query.

22 Z. Bukowski, Konstytucyjne podstawy obowiązków państwa w zakresie ochrony środowiska, „Prawo i Środowisko” 2002, nr 4, s. 63. 
generalnie nakreślonym, ale i pierwszoplanowym celem dla prawa administracyjnego jest ochrona dobra wspólnego zharmonizowanego $z$ dobrem jednostek ${ }^{23}$.

Jak wskazano w piśmie z 7 maja 2018 r. w założeniu legalizacja polowania z łukiem nie miałaby doprowadzić do zastąpienia stosowanej dotychczas legalnie broni palnej, ale spowodowałaby rozszerzenie arsenału dla wszystkich myśliwych ${ }^{24}$. Zauważyć należy, że obecnie do celów polowania używana może być jedynie: myśliwska broń palna długa centralnego zapłonu, o lufach gwintowanych lub gładkich, $z$ wyłączeniem broni czarnoprochowej, pistoletów i rewolwerów, $z$ której po maksymalnym załadowaniu można oddać najwyżej sześć pojedynczych strzałów, $z$ tym że do magazynka broni samopowtarzalnej można załadować jednorazowo najwyżej dwa naboje ${ }^{25}$.

Jak zaznaczono, celem proponowanego rozwiązania jest spełnianie potrzeb społecznych w zakresie uprawiania myślistwa, kultywowania tradycji oraz krzewienia etyki i kultury łowieckiej ${ }^{26}$. Odnotować należy, że powyższe przesłanki zaczerpnięte zostały z cytowanego wyżej art. 3 pkt 4 u.p.ł. Podkreślenia wymaga, że użycie wyrażenia „kultywowanie tradycji” w odniesieniu do strzelania z łuku może być potraktowane jako dyskusyjne, ponieważ nowoczesne prawo łowieckie traktuje taki sposób pozyskiwania zwierzyny jako kłusownictwo. Dodatkowo, spełnienie potrzeb społecznych zostało wskazane jako realizacja interesu prawnego. Należy wskazać, że treść pojęcia interes prawny stanowi: publiczne prawo podmiotowe, rozumiane jako przyznanie przez przepis prawa jednostce konkretnych korzyści, które można realizować w postępowaniu administracyjnym ${ }^{27}$. Należy wyjaśnić, że z normy prawnej zawartej w art. 3 pkt 4 u.p.ł. nie wynika żadne publiczne prawo podmiotowe, którego może się domagać jednostka - w szczególności poprzez modyfikację obowiązującego ustawodawstwa.

Ponadto, proponuje się zamknięcie drogi do łucznictwa myśliwskiego dla osób pozbawionych prawa do posiadania broni czy skazanych za przestępstwa kłusownicze ${ }^{28}$. Pomijając fakt, że obecnie strzelanie do zwierzyny z łuku jest kłusownictwem, należy także dostrzec, że łuk nie został wymieniony jako broń

23 Z. Duniewska [w:] System prawa administracyjnego, t. 1, Instytucje prawa administracyjnego, red. R. Hauser, Z. Niewiadomski, A. Wróbel, Warszawa 2015, s. 104.

24 J. Kylmä, Rozwój myślistwa, op. cit.

25 Rozporządzenie Ministra Środowiska z 23 marca 2005 r. w sprawie szczegółowych warunków wykonywania polowania i znakowania tusz, Dz.U. nr 61, poz. 548, ze zm.

26 Pismo z 7 maja 2018 r., cz. II. Uzasadnienie do proponowanych zmian prawa łowieckiego.

27 J. Borkowski, Komentarz do art. 28 ustawy z dnia 14 czerwca 1960 r. - Kodeks postępowania administracyjnego (t. j. Dz. U. z 2017 r., poz. 1257 ze zm.) [w:] B. Adamiak, J. Borkowski, Kodeks postępowania administracyjnego. Komentarz, Warszawa 2006, s. 225.

28 Pismo z 7 maja 2018 r., op. cit., pkt 2 - Wysoki poziom akceptacji społecznej szansa na odnowienie wizerunku łowiectwa. 
w ustawie o broni i amunicji. Jednakże, jako narzędzie lub urządzenie, którego używanie może zagrażać życiu i zdrowiu, została wymieniona w powołanej ustawie broń cięciwowa w postaci kusz (art. 4 ust. 1 pkt 4 lit. b u.b.a.) - czyli również broń tzw. neurobalistyczna.

W uzasadnieniu proponowanego rozwiązania wskazuje się również, że brak efektów akustycznych w postaci huku wystrzału znacznie ogranicza płoszenie zwierząt ${ }^{29}$. Z uwagi na domniemaną racjonalność ustawodawcy zauważenia w tym miejscu wymaga, że wprawdzie, jak wyżej wskazano, łuk nie jest bronią w rozumieniu ustawy o broni i amunicji, natomiast nie wydaje się pozwolenia na broń szczególnie niebezpieczną, do której należy broń palna wyposażona w tłumik huku lub przystosowana do strzelania z użyciem tłumika huku (art. 10 ust. 5 pkt 3 u.b.a.).

Propozycję wprowadzenia polowania z łuku uzasadnia się m.in. pośrednio także szczególnym charakterem więzi rodzącej się między rodzicami a dzieckiem, wspólnie pokonującymi trasę terenowych zawodów łuczniczych ${ }^{30}$. Dostrzec należy, że użyto sformułowania „zawody łucznicze”. W tym miejscu warto podkreślić, że argumentacja oparta na stwierdzeniu, iż zastosowanie łuku w myślistwie doprowadzi do zwiększenia zainteresowania młodzieży, wskazuje na aktywność zaliczaną do sportu - podczas gdy łowiectwo sportem nie jest ${ }^{31}$. Łowiectwo oznacza bowiem ochronę zwierząt łownych (zwierzyny) i gospodarowanie ich zasobami w zgodzie z zasadami ekologii oraz zasadami racjonalnej gospodarki rolnej, leśnej i rybackiej (art. 1 u.p.ł.). Co więcej, przypomnienia wymaga, że ustawodawca polski w ostatnim czasie zabronił wykonywania polowania w obecności lub przy udziale dzieci do 18. roku życia (art. 42aa pkt 15 u.p.ł.) pod groźbą grzywny, kary ograniczenia wolności albo pozbawienia wolności do roku (art. 52 pkt 7 u.p.ł.) ${ }^{32}$. Trudno zatem przypuszczać, aby uzasadnienie omawianej propozycji zainteresowaniem niepełnoletnich osób nowym rodzajem broni używanej do polowania pozostawało w spójności z powyższą zmianą legislacyjną. Powyższe uzasadnienie nie wydaje się także trafne $\mathrm{z}$ uwagi na ustawowy zakaz wydawania pozwolenia na broń osobom niemającym ukończonych 21 lat (art. 15 ust. 1 pkt 1 u.b.a.). Należy zauważyć, że ustawowego wyjątku, dozwalającego na wydanie takiego pozwolenia osobie mającej ukończone 18 lat na wniosek m.in. Polskiego Związku Łowieckiego (art. 15 ust. 2 u.b.a.) nie należy interpretować rozszerzająco.

Ponadto, w uzasadnieniu do propozycji argumentuje się, że myśliwi łucznicy w sposób istotny realizują działania odpowiadające na realne potrzeby społecz-

29 Ibidem, pkt 8 - Łuk w gospodarce łowieckiej.

$30 \quad$ Ibidem, pkt 2 - Wysoki poziom akceptacji społecznej szansa na odnowienie wizerunku towiectwa.

31 E.J. Krześniak, Kluby i organizacje, op. cit.

32 Art. 1 ustawy z 22 marca 2018 r. o zmianie ustawy - Prawo łowieckie oraz niektórych innych ustaw, Dz.U. poz. 651. 
ne - np. redukcję zwierzyny na terenach miejskich i ograniczenie jej migracji na tereny podmiejskie, redukcję zwierzyny przyczyniającej się do znacznych szkód leśnych oraz rolnych ${ }^{33}$. Wydaje się, że powyższa argumentacja wymagałaby szczegółowych badań mających na celu ustalenie, czy łucznictwo myśliwskie rzeczywiście spełnia wymogi gospodarki łowieckiej, o której mowa w art. 4 ust. 1 u.p.ł.

Podsumowując, należy stwierdzić, że odnalezienie dobra wspólnego w umożliwieniu polowania z łuku może być problematyczne. Jak powyżej wskazano, istnienie tego dobra jest warunkiem koniecznym do wprowadzenia nowej regulacji. W orzecznictwie Trybunału Konstytucyjnego wskazano bowiem w kontekście art. 1 Konstytucji RP, że z faktu, iż Rzeczypospolita Polska jest dobrem wspólnym wszystkich obywateli: wynika (...) dyrektywa przedłożenia $w$ razie potrzeby dobra ogólnego ponad dobro indywidualne czy partykularny interes grupowy ${ }^{34}$. W odniesieniu do proponowanej koncepcji wydaje się, że nie została ona uzasadniona istnieniem takiego wspólnego dobra prawnie relewantnego, które mogłoby zostać pozyskane jedynie poprzez legalizację polowania $\mathrm{z}$ łuku.

\section{Polowanie z łuku a konstytucyjny obowiązek zapewnienia bezpieczeństwa}

Analizując przedmiotową koncepcję legislacyjną, nie należy pomijać konstytucyjnego obowiązku zapewnienia bezpieczeństwa obywatelom (art. 5 Konstytucji $\mathrm{RP})$. Obowiązek taki ciąży na państwu również w odniesieniu do wzajemnych relacji pomiędzy obywatelami ${ }^{35}$.

W tym kontekście istotna może się okazać nie tylko wspomniana kwestia bezgłośnego polowania (i obowiązujący zakaz wydawania pozwolenia na broń palną wyposażoną w tłumik huku jako na broń szczególnie niebezpieczną), ale także ogólne bezpieczeństwo podczas polowania.

Z uwagi na prawny charakter opinii nie sposób odnieść się merytorycznie do przedstawianych w tym zakresie argumentów, jednak zauważyć trzeba, że z jednej strony powołano się na fakt kilkunastokrotnie mniejszej szansy łucznika na skuteczne polowanie niż klasycznego myśliwego $\mathrm{z}$ bronią palną ${ }^{36}, \mathrm{z}$ drugiej natomiast strony podkreślono, że doświadczony myśliwy posługujący się łukiem uzyskuje podobne wyniki w pozyskiwaniu grubej zwierzyny jak myśliwi uzbrojeni w broń palną ${ }^{37}$ oraz że odpowiednio przygotowany i skonfigurowany sprzęt

33 Pismo z 7 maja 2018 r., op. cit., pkt 2 - Wysoki poziom akceptacji społecznej szansa na odnowienie wizerunku łowiectwa.

34 Wyrok Trybunału Konstytucyjnego z 30 stycznia 2001 r., sygn. akt K 17/00, OTK ZU 2001, nr 1, poz. 4.

35 M. Florczak-Wątor, Komentarz do art. 5 [w:] Konstytucja RP, t. I, Komentarz. Art. 1-86, red. M. Safjan, L. Bosek, Warszawa 2016.

36 Pismo z 7 maja 2018 r., op. cit., pkt 2 - Wysoki poziom akceptacji społecznej szansa na odnowienie wizerunku łowiectwa.

37 Ibidem, pkt 8 - Łuk w gospodarce łowieckiej. 
charakteryzuje się najwyższym wskaźnikiem bezpieczeństwa ${ }^{38}$. Żadna z powyższych tez nie znalazła jednak potwierdzenia w dokumentacji, zawierającej wyniki niezależnych badań czy opinie niezależnych ekspertów. W kontekście bezpieczeństwa na tle skuteczności myślistwa łuczniczego wątpliwości budzi także polowanie na terenach zurbanizowanych oraz w bezpośrednim sąsiedztwie zabudowań ${ }^{39}$.

\section{Podsumowanie}

Powyższa analiza prowadzi do kilku wniosków.

Z uwagi na zasadę zrównoważonego rozwoju oraz umieszczenie ustawy Prawo łowieckie w systemie ochrony środowiska przyrodniczego dopuszczenie strzelania z łuku jako metody polowania na terenie Rzeczypospolitej Polskiej może budzić wątpliwości. Jednocześnie wprowadzenie łuku jako dopuszczalnej broni myśliwskiej może budzić wątpliwości z uwagi na konstytucyjny obowiązek zapewnienia bezpieczeństwa obywatelom. Jednakże konieczność ograniczenia się do analizy prawnej omawianego zagadnienia nie pozwala na udzielenie jednoznacznej odpowiedzi.

Wydaje się, że wprowadzenie regulacji dopuszczającej polowanie z łukiem znalazłoby racjonalne uzasadnienie dopiero w sytuacji, gdy na podstawie niezależnie przeprowadzonych badań naukowych znalazłaby potwierdzenie teza, że łuk jest co najmniej tak samo skuteczny dla celów gospodarki łowieckiej oraz jednocześnie stanowi broń co najmniej tak samo humanitarną i bezpieczną jak dotychczas stosowana broń palna myśliwska.

\section{Bibliografia}

Bartoszewicz M., Komentarz do art. 74 [w:] Konstytucja Rzeczypospolitej Polskiej. Komentarz, red. M. Haczkowska, Warszawa 2014.

Borkowski J., Komentarz do art. 28 ustawy z dnia 14 czerwca 1960 r. - Kodeks postępowania administracyjnego (t. j. Dz. U. z 2017 r., poz. 1257 ze zm.) [w:] B. Adamiak, J. Borkowski, Kodeks postępowania administracyjnego. Komentarz, Warszawa 2006.

Bukowski Z., Konstytucyjne podstawy obowiązków państwa w zakresie ochrony środowiska, „Prawo i Środowisko” 2002, nr 4.

Duniewska Z. [w:] System prawa administracyjnego, t. 1, Instytucje prawa administracyjnego, red. R. Hauser, Z. Niewiadomski, A. Wróbel, Warszawa 2010.

38 Ibidem, pkt 3 - Najwyższe wskaźniki bezpieczeństwa podczas polowania.

39 Ibidem, pkt 4 - Polowanie na terenach zurbanizowanych oraz $w$ bezpośrednim sąsiedztwie zabudowań. 
Florczak-Wątor M., Komentarz do art. 5 [w:] Konstytucja RP, t. I, Komentarz. Art. 1-86, red. M. Safjan, L. Bosek, Warszawa 2016.

Gardocka T., Czy w polskim prawie karnym potrzebny jest kontratyp sztuki?, „Palestra” 2015, nr 1-2.

Krześniak E.J., Kluby i organizacje sportowe w prawie polskim. Na tle rozwiązań zagranicznych, Warszawa 2016.

Radecki W., Komentarz do art. 53 Prawa łowieckiego [w:] System prawa karnego, t. 11, Szczególne dziedziny prawa karnego. Prawo karne wojskowe, skarbowe i pozakodeksowe, red. M. Bojarski, Warszawa 2014.

Sarnecki P., Komentarz do art. 5 [w:] Konstytucja Rzeczypospolitej Polskiej. Komentarz, t. I, red. L. Garlicki, M. Zubik, Warszawa 2016.

Stec R., Łowiectwo w prawie polskim i europejskim, Warszawa 2002.

Stec R., Uprawianie łowiectwa i prowadzenie gospodarki łowieckiej. Uwarunkowania administracyjnoprawne, cywilnoprawne i organizacyjne, Warszawa 2012. 